\title{
Serum Ciliotoxic Activity in Mutant Mice with Some Hereditary Alterations Resembling Cystic Fibrosis
}

\author{
OMAR H. PIVETTA, MABEL L. LABAL, AND DANIEL O. SORDELLI
}

Centro Nacional de Genética Médica, Buenos Aires, Argentina

\section{Summary}

Serum ciliotoxic activity (SCA), which had been described in cystic fibrosis (CF), was studied in mutant mice with some hereditary alterations resembling this inherited disease.

A test was developed to detect SCA in biologic fluids by means of a natural vibratile system; it consisted in the incubation of mouse sperm with different $\mathrm{CF}$ serum dilutions under controlled conditions, in order to determine the sperm translation cessation time (STCT) and the sperm activity cessation time (SACT). As the findings of this study were similar to those obtained by other authors who have been employing alternative systems, it was decided to apply this method on mice serum. Sera were obtained from male and female 3- to 4-wk-old mice of DBA/2J-cri, C57BL/ $6 \mathrm{~J}-b g^{\mathrm{J}}$, and BALB/c inbred strains; SCA was investigated in affected homozygotes and their $+/$ ? siblings were used as controls. Male 8- to 16-wk-old BALB/c mice were employed as sperm donors. Significant differences were found between cri/cri and $+/$ ? mice of the DBA/2J-cri strain in both STCT and SACT determinations at $1 / 10$ serum dilution.

It is concluded that mouse sperm is a system sensitive enough to detect SCA in biologic fluids from human beings. Likewise, the test of the mouse sperm allowed us to detect SCA in cri/cri mice, turning this mutation into a possible animal model for $\mathrm{CF}$.

\section{Speculation}

Homozygous mice for the cri gene of the DBA/2J-cri strain show electrolyte alterations and a decreased lung clearance of Staphylococcus aureus. The presence of SCA in these mutants, also frequently observed in $\mathrm{CF}$ patients, lends support to the concept of a CF animal model.

$\mathrm{CF}$ is the most frequent lethal inherited disease that affects caucasian children (9). The basic defect remains unknown, but there is a general agreement that CF is due to an inborn error of metabolism transmitted as an autosomal recessive trait (8). Conclusive evidence has been accumulated regarding the ciliotoxic properties of several CF corporal fluids, such as serum (18) and saliva (11). The ciliotoxic activity as early attributed to a thermolabile, nondyalizable factor, which precipitates with the euglobulin fraction (18); the first determination of the molecular weight yielded values oscillating between 125,000-200,000 (3) because of its association in serum to a $\gamma$-globulin. Subsequently, this factor was identified as a cationic protein with a molecular weight ranging from $5000-11,000$ (2). It produces asynchronism in the ciliar beating of rabbit tracheal mucosa explants (18), total stopping of the ciliar movement in oyster (4) and mussel gills (1), cytolysis of ciliated protozoa (19), and bacterial agglutination (5) when exposed those ciliar systems to CF patients or obligatory heterozygote sera. The SCA has not been observed in normal human beings. Nevertheless, Conover et al. (6) have demonstrated SCA, equivalent to that found in CF children, in patients suffering from different types of pulmonary or immunologic illness.
As there seems to exist a relationship between the ciliostatic effect and the primary genetic abnormality, the study of this effect in search for a CF animal model was undertaken. A simple and reproducible procedure was developed to detect the presence of the CF gene, employing sperm from the experimental Mus musculus mouse as ciliary system. In the present paper, this procedure is described along with human SCA, as well as the application of this bioassay to different inbred strains of mice bearing hereditary alterations resembling $C F$.

\section{MATERIALS AND METHODS}

\section{HUMAN SUBJECTS}

A total of 32 individuals were studied. All the blood samples were obtained while they were fasting. The CF patients met all three criteria for the diagnosis of the disease (20). They were in stable condition, and at the time of analysis generally showed moderate pulmonary involvement (mean Schwachman score 70). Both CF patients and obligatory heterozygotes were all caucasians as well as the control volunteers, who were in good health and had no family history of CF. The number of individuals and their age ranges in years, respectively, were as follows: 1) controls: male: 5, 18-33 yr; female: $5,25-50$ yr. 2) CF patients: male: 3, 7-20 yr; female: 3, 6-19 yr. 3) CF obligatory heterozygotes: male: 6, 25-50 yr; female: 6, 26-45 yr.

Blood samples were collected with nonheparinized syringes, incubated at $37^{\circ} \mathrm{C}$ during $30 \mathrm{~min}$, and centrifuged at $3000 \mathrm{RPM}$ for $20 \mathrm{~min}$. Two aliquots of each serum were prepared: one was used within the 1 st hr after collection and the 2 nd, which was kept at $-20^{\circ} \mathrm{C}$, was used $24 \mathrm{hr}$ later. Both fresh and freezing-stored sera were diluted $1 / 2,1 / 10$, and $1 / 100$ in saline solution $(\mathrm{NaCl}$ $0.15 \mathrm{M})$ to be used for sperm confrontation.

MICE

Male and female 3- to 4-wk-old Mus musculus mice of three inbred strains were used in this work. Two of them, DBA/2J-cri and $\mathrm{C} 57 \mathrm{BL} / 6 \mathrm{~J}-b^{\mathrm{J}}$, were chosen because they showed some similarities to human CF patients. The 3rd strain, BALB/c, was employed as control and as sperm donor; the latter did not present any striking abnormality, except for being albino mice. Homozygotes for the autosomal recessive cri gene have an impaired electrolytical metabolism $(13,15)$, cribriform degeneration of the central nervous system (12), and a diminished pulmonary clearance of Staphylococcus aureus (17). Homozygotes for the autosomal recessive $b g$ gene suffer from spontaneous pneumonitis over the 6th month of age (14). The $+/$ ? siblings of each strain were employed as controls; $+/$ ? population was composed of $1 / 3$ of $+/+$ individuals and $2 / 3$ of $c r i /+$ and $b g /+$ heterozygotes of the $\mathrm{DBA} / 2 \mathrm{~J}-$ cri and C57BL/6J-bg' strains, respectively.

Blood was obtained from a venous sinus in the inner canthus of the eye using nonheparinized capillary tubes; they were incubated at $37^{\circ} \mathrm{C}$ during $30 \mathrm{~min}$ and centrifuged at $12,000 \mathrm{RPM}$ for $15 \mathrm{~min}$; sera were diluted $1 / 10$ and $1 / 2$ in saline for sperm confrontation. 


\section{CILIARY BIOASSAY}

Male, BALB/c mice, 8- to 16-wk-old, were used as sperm donors. They were killed by cervical dislocation; the epididymis head was excised through an abdominal incision and macerated in $2.5 \mathrm{ml}$ of saline in order to obtain a sperm suspension that was observed under microscope at $100 \times$ to check motility. The mean concentration of sperm used was $1.8 \times 10^{6} \mathrm{sperm} / \mathrm{ml}$, in a range of $1.3-2.9 \times 10^{6} \mathrm{sperm} / \mathrm{ml}$. Sperm motility was assayed with a technique developed in our laboratory that has been previously reported (16). In brief, it consists in the confrontation of $0.1 \mathrm{ml}$ of diluted serum with $0.1 \mathrm{ml}$ of mouse sperm suspension in a tripleexcavated slide in a wet chamber. Each run includes 2 serum samples in a determined dilution and a saline control (without serum), all of them in triplicate, which amounts to nine simultaneous confrontations. When a serum from CF patient was tested, a serum from the parent of the same sex was run at the same time; when an affected homozygous mouse serum was assayed, a serum from its $+/$ ? sibling of the same sex was run simultaneously. After 2 min of mixing, each individual confrontation was checked at the microscope every $3 \mathrm{~min}$ at $100 \times$. The time that no more sperm translation was observed and the time when no more sperm flagellum activity was detected were both recorded. Each tabulated time value was the arithmetic mean of the three registered times. The whole procedure was carried out at temperatures oscillating between $22-28^{\circ} \mathrm{C}$ and the test was read in a double blind fashion. The bioassay was expressed in min as: 1) STCT: is the time when no more sperm translation was observed. At this moment, their flagella still kept an in situ swinging movement. 2) SACT: is the time when the last sperm stopped its flagellum swinging movement. At this moment, no single flagellar movement was detected in the test chamber.

Statistical evaluations were carried out applying Dixon's test for extreme anomalous data (10). In order to investigate a possible sex difference in STCT and SACT, a statistical study was made on each individual group. None of the cases showed significant differences; so that, the data from males and females were grouped together, for each genotype. When a pair of arithmetic means was compared, a Student's $t$ test was employed to determine whether they were estimators of the same population mean. When more than two means were compared, a variance analysis was made with one criterion of classification.

\section{RESULTS}

\section{HUMAN SERUM CILIOTOXIC ACTIVITY ON MOUSE SPERM}

A progressive decrease in sperm translation was observed during the confrontation, and gradually they became motionless while their flagella still kept the swinging beating. After a little time, the sperm lost all movement. The results of STCT and SACT for the employed dilutions of human sera are shown in Figure 1. In all cases, sperm confronted with saline were the last to stop their activity. It was observed that both STCT and SACT values always decreased with the increase in serum concentration in all the groups studied; the best differences between $C F$ patients and controls were noted in SACT using fresh sera at $1 / 2$ and $1 / 10$ dilutions $(P<0.01$ and $P<0.05$, respectively), and in STCT using fresh sera at $1 / 10$ dilution $(P<0.05)$.

Sera samples frozen at $-20^{\circ} \mathrm{C}$ for $24 \mathrm{hr}$ modified their SCA, and the differences among groups were not significant. The method was useless to detect SCA with fresh sera at both $1 / 100$ and $1 / 1$ dilutions. In view of these results it was decided to choose fresh serum at $1 / 2$ and $1 / 10$ dilutions for routine testing of ciliotoxic activity.

\section{SERUM CILIOTOXIC ACTIVITY IN MICE}

As it is shown in Table 1, when sperm suspension was confronted to $1 / 2$ and $1 / 10$ dilutions of BALB/c mice sera, STCT and SACT were significantly higher $(P<0.001)$ than the other studied groups. Homozygotes for the cri gene showed significant differences in STCT and SACT when compared to their $+/$ ?

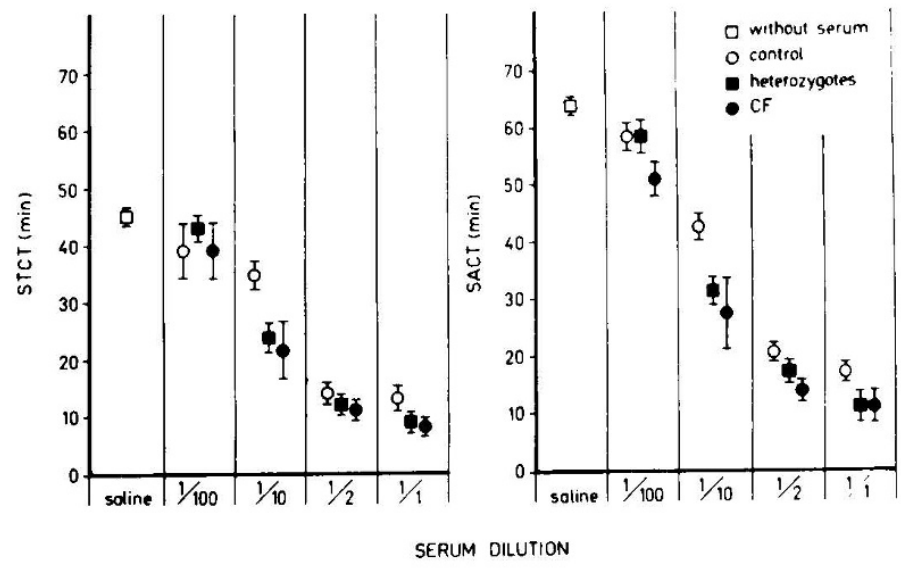

Fig. 1. STCT and SACT from sera of CF patients, CF obligatory heterozygotes and normal controls for different serum dilutions. Each point represents the arithmetic mean \pm SE: each mean value was obtained from 6-12 confrontations, made in triplicate.

siblings. It was possible to detect ciliary ciliotoxic activity in cri/ cri mice using $1 / 10$ serum dilution; at $1 / 2$ dilution, the differences concerning $+/$ ? siblings were not significant. In all cases, STCT and SACT for mice serum were higher than saline controls; on the other hand, the last values were higher than the same obtained with human sera. No significant differences were detected between $b g / b g$ and $+/$ ? mice of the C57BL/6J- $b g^{J}$ strain.

\section{DISCUSSION}

A method capable of detecting SCA was designed; CF patients and obligatory heterozygotes sera, which frequently exhibited ciliotoxic property, were taken as reference. The technique was applied to investigate SCA in sera from mice with some abnormalities similar to those found in $\mathrm{CF}$ patients.

It is well known that SCA is not a reliable individual characteristic for screening of $\mathrm{CF}$ heterozygotes because it is not always demonstrable in CF patients and obligatory heterozygotes. In fact, in the present study an overlapping was found between homozygotes and heterozygotes in both STCT and SACT values; nevertheless, this procedure, applied to human patients, allowed us to make the identification of individual carriers of the $C F$ gene out of a normal population. Sperm flagella from BALB/c mice seem to be sensitive to the $\mathrm{CF}$ ciliotoxic action. The best serum dilutions to observe differences in SCA were $1 / 10$ and $1 / 2$. The $1 / 10$ dilution had been employed successfully by Wilson and Jahn (19) in their studies on detection of the CF serum factor producing cytolysis of Colpidium striatum. As reported (21), freezing of serum could decrease SCA to such a point that it becomes undetectable; so that for SCA bioassay in mice only fresh serum can be employed.

The advantage of this inexpensive method lies in its simplicity and fast determination in contrast to other methods, such as those requiring cell culture $(7,18)$. In addition, these vibratile cells come from an animal that does not possess any particular problem of environmental adaptation; moreover, sperm production is not greatly affected by seasonal variations. Saline control was included in order to verify the reproducibility of the sperm motility level in each experiment. All the human STCT and SACT mean values were lower than those obtained for the saline controls, which in turn, resulted lower than mouse STCT and SACT values. This may be related to the respectively heterologous or homologous character of the confrontation systems when human or mouse sera were tested. The significant differences found in STCT and SACT between cri/cri and their $+/$ ? controls suggest the existence of a ciliotoxic serum factor, which may be related to the same factor described in human CF serum. As observed in human sera, 1/10 was a sensitive dilution to detect mice SCA. Homoscedasticity for $c r i / c r i$ and their control siblings for STCT and SACT did not allow the detection of the mixed composition of the $+/$ ? popula- 


\begin{tabular}{|c|c|c|c|c|c|c|c|}
\hline \multirow{3}{*}{$\begin{array}{l}\text { Determina- } \\
\quad \text { tion }\end{array}$} & \multirow{3}{*}{$\begin{array}{l}\text { Sera dilu- } \\
\text { tion }\end{array}$} & \multirow[b]{3}{*}{ Saline solution } & \multicolumn{5}{|c|}{ Strains of mice } \\
\hline & & & \multirow[b]{2}{*}{$\mathrm{BALB} / \mathrm{c}$} & \multicolumn{2}{|c|}{ DBA/2J-cri } & \multicolumn{2}{|c|}{ C57BL/6J-bg' } \\
\hline & & & & cri/cri & $+/ ?$ & $\mathrm{bg} / \mathrm{bg}$ & $+/ ?$ \\
\hline \multirow[t]{3}{*}{ STCT } & & $47 \pm 2(36)^{1}$ & & & & & \\
\hline & $1 / 10$ & & $142 \pm 7(5)$ & $88 \pm 4(19)^{2}$ & $105 \pm 4(24)$ & $99 \pm 6(12)$ & $93 \pm 3(11)$ \\
\hline & $1 / 2$ & & $144 \pm 17(5)$ & $88 \pm 4(19)$ & $92 \pm 6(24)$ & $83 \pm 5(12)$ & $91 \pm 2(11)$ \\
\hline \multirow[t]{3}{*}{ SACT } & & $59 \pm 1(36)$ & & & & & \\
\hline & $1 / 10$ & & $152 \pm 10(5)$ & $102 \pm 4(19)^{2}$ & $124 \pm 4(24)$ & $115 \pm 5(12)$ & $106 \pm 3(11)$ \\
\hline & $1 / 2$ & & $152 \pm 16(5)$ & $102 \pm 4(19)$ & $111 \pm 5(24)$ & $102 \pm 5(12)$ & $104 \pm 4(11)$ \\
\hline
\end{tabular}

$1 \bar{x} \pm S E(n)$

${ }^{2}$ Significant difference with $P<0.0$ l with respect to the $+/$ ? group of the same strain.

tion. The $+/$ ? group is probably composed of $1 / 3$ of $+/+$ and $2 /$ 3 of $\mathrm{cri} /+$ individuals, phenotypically not differentiable. In this way, the ciliotoxic behavior of mouse serum seems not to be identical with CF human serum in which no differences were seen between obligatory heterozygotes and affected homozygotes. The highest values of STCT and SACT were obtained when both BALB/c sperm and serum were confronted, probably due to the syngeneic nature of this system. On the other hand, the results obtained in DBA/2J-cri and C57BL/6J- $b g^{\mathrm{J}}$ strains were significantly lower than those obtained for BALB/c mice. Because $+/$ + and the heterozygotes of those two strains were not available, it is difficult to speculate about the differences found among strains. The similarity in both STCT and SACT between $b g / b g$ and $+/$ ? control siblings of the C $57 \mathrm{BL} / 6 \mathrm{~J}-\mathrm{bg}^{\mathrm{J}}$ inbred strain of mice, suggest the absence of SCA in these mutants.

From an experimental point of view, it is interesting to note the simultaneous presence of an impaired electrolyte metabolism, a diminished pulmonary clearance of Staphylococcus aureus, and serum ciliotoxic properties associated with an autosomic recessive mutation in an inbred strain of mice (DBA/2J-cri). In conclusion, the demonstration of SCA in cri/cri homozygotes supports their proposition as animal model for $\mathrm{CF}$.

\section{CONCLUSION}

Serum ciliotoxic activity, also found in CF patients, was investigated in different inbred strains of mice. After having developed a simple test to detect SCA in CF patients using mouse sperm as ciliary system, it was applied to mouse serum. It was chosen DBA/ $2 \mathrm{~J}$-cri and $\mathrm{C} 57 \mathrm{BL} / 6 \mathrm{~J}-\mathrm{bg}^{\mathrm{J}}$ mutant mice because they show several alterations resembling cystic fibrosis; BALB/c mice were used as controls and as sperm donors. The results obtained suggest the existence of SCA, similar to that found in CF patients, in cri/cri homozygotes of the DBA/ $2 \mathrm{~J}$-cri strain. Thus, their use as animal model for CF studies is suggested.

\section{REFERENCES AND NOTES}

1. Beasley, G. T. N., Patrick, A. D., and Norman, A. P.: Inhibition of the motility of gill cilia of Dreissensia by plasma of cystic fibrosis patients and their parents. J. Med. Genet., 6: 278 (1969).

2. Bowman, B. H., Lankford, B. J., Fuller, G. M., Carson, S., Kurosky, A., and Barnett, D. R.: Cystic fibrosis: the ciliary inhibitor is a small polypeptide associated with immunoglobulin G. Biochem. Biophys. Res. Commun., 64: 1310 (1975).
3. Bowman, B. H., Lockhart, L. H., and McCombs, M. L.: Oyster ciliary inhibition by CF factor. Science, 164: 325 (1969)

4. Bowman, B. H., McCombs, M. L., and Lockhart, L. H.: Cystic fibrosis: characterization of the inhibitor to ciliary action in oyster gills. Science. 167: 871 (1970).

5. Cohen, F. L., and Daniel, W. L.: Effects of cystic fibrosis sera on Proteus vulgaris motility. J. Med. Genet., 11: 253 (1974).

6. Conover, J. H., Conod, E. J., and Hirschorn. K.: Ciliary-dyskinesia factor in immunological and pulmonary disease. Lancet. 7813: 1194 (1973).

7. Danes, B. S., and Bearn, A. G.: Oyster ciliary inhibition by cystic fibrosis culture medium. J. Exptl. Med., 136: 1313 (1972).

8. Danks, D. M., Allan, J., and Anderson, C. M.: A genetic study of fibrocystic of the pancreas. Ann. Hum. Genet., 28: 323 (1965).

9. Di Sant'Agnese, P. A., and Davis, P. B.: Medical progress: research in cystic fibrosis. N. Engl. J. Med., 295: 481 (1976).

10. Dixon, W. J.: Processing data for outliers. Biometrics, 9: 74 (1953)

11. Dogget, R. G., and Harrison, G. M.: Cystic fibrosis: reversal of ciliary inhibition in serum and saliva by heparin. Tex. Rep. Biol. Med., 31: 685 (1973).

12. Green, M. C., Sidman, R. L., and Pivetta, O. H.: Cribriform degeneration (cri): a new recessive neurological mutation in the mouse. Science, 176: 800 (1973)

13. Kaiser, D. Pivetta, O. H., and Rennert, O. M.: Autosomal recessively inherited electrolyte excretory defect in the parotid of the "cribriform degeneration" mouse mutant. Possible analogy to cystic fibrosis. Life Sci., 15: 803 (1974).

14. Lane, P. W., and Murphy, E. A.: Susceptibility to spontaneous pneumonitis in an inbred strain of mice. Genetics, 72: 451 (1972).

15. Pivetta, O. H., and Green. M. C.: Preferencia salina y anormalidades electroliticas en ratones mutantes con degeneración cribiforme (cri). Medicina. 37: 379 (1977).

16. Pivetta, O. H., Labal, M. L., and Sordelli, D. O.: Efecto del suero de mutaciones de ratones con alteraciones similares a la enfermedad fibroquística del páncreas (EFQP), sobre la motilidad del espermatozoide de ratón BALB/c. VI Congreso Argentino de Genética, Castelar, Buenos Aires (1975).

17. Pivetta, O. H. Sordelli, D. O., and Labal, M. L. Pulmonary clearance of Staphylococcus aureus in mutant mice with some hereditary alterations resembling cystic fibrosis. Pediatr. Res., 11: 1133 (1977).

18. Spock. A., Heick, H. M. C.. Cress, H., and Logan, W. S.: Abnormal serum factor in patients with cystic fibrosis of the pancreas. Pediatr. Res, $l: 173$ (1967).

19. Wilson. G. B.. and Jahn. T. L.: Decreased rate of cytolysis of Colpidium striatum by cystic fibrosis serum. I. Bioassay and evidence for the possible involvement of a CF factor-IgG complex. Life Sci.. 15: 551 (1974).

20. Wood. R. E., Boat. T. F., and Doershuk, C. F.: State of the Art. Cystic fibrosis. Am. Rev. Respir. Dis., 113: 833 (1976).

21. Wood. R. E., and Di Sant Agnese. P. A.: Bioassays of cystic fibrosis factor Lancet, 2: 1452 (1973).

22. The authors thank Mrs. Luisa Rodriguez for technical assistance and Mrs. Susana $\mathrm{Paz}$ for secretarial work.

23. Omar H. Pivetta. M.D., Member of Research Career CONICET (Consejo Nacional de Investigaciones Cientificas y Técnicas)-Buenos Aires.

24. This research was supported by grants from the Cystic Fibrosis Foundation (U.S.A.).

25. Requests for reprints should be addressed to: Dr. Omar H. Pivelta. Centro Nacional de Genética Médica. Combate de los Pozos 2193. 1245 Buenos Aires. Argentina.

26. Received for publication October 20, 1977

27. Accepted for publication November $7,1978$. 